\title{
Bifurkasi pada Sistem Lorenz Modifikasi
}

\author{
Fadilah Ilahi ${ }^{1, a)}$, Asri Puji Lestari ${ }^{1, b)}$ \\ 1)Jurusan Matematika, Fakultas Sains dan Teknologi, UIN Sunan Gunung Djati Bandung \\ a)fadilah.ilahi@uinsgd.ac.id \\ ${ }^{\text {b) } \text { asripujilestari@rocketmail.com }}$
}

\begin{abstract}
Abstrak
Penelitian ini membahas sistem Lorenz modifikasi yang menggambarkan pergerakan angin di atmosfer yang mengalami turbulensi karena adanya perubahan temperatur yang dipengaruhi oleh intensitas gerak fluida, temperatur horizontal serta temperatur vertikal. Sistem ini memiliki tiga parameter real, yaitu parameter yang menentukan distribusi temperatur, nilai yang bergantung dengan keadaan geometri suatu fluida serta nilai perbedaan temperatur antara bagian atas dan bagian bawah lapisan. Analisis dinamik pada sistem ini menentukan titik ekuilibrium, nilai eigen serta menentukan kestabilan dari setiap titik ekuilibrium. Sistem ini memiliki dua titik ekuilibrium. Berdasarkan analisis yang telah dilakukan diperoleh bahwa titik ekuilibrium yang pertama dinyatakan tidak stabil dan titik ekulibrium yang kedua stabil bersyarat. Untuk mengetahui bifurkasi dari sistem ini, diambil 27 kondisi dengan parameter yang berbeda-beda. Dengan mengambil 27 kondisi ini dapat dilihat perubahan kestabilannya. Karena adanya perubahan kestabilan, maka sistem ini termasuk bifurkasi transcritical. Limit cycle yang terbentuk adalah limit cycle stabil karena bagian luar dan dalam limit cycle mendekati limit cycle.
\end{abstract}

Kata kunci: Bifurkasi, Kestabilan, Sistem Lorenz, Sistem Lorenz Modifikasi, Titik Ekuilibrium.

\section{Abstract}

This research discusses a modified Lorenz system, this system represent wind motion in the atmosphere be through of turbulence due temperature are changed, that is influenced by the intensity of fluid motion, horizontal temperature and vertical temperature. The system has three real parameters, which are determine the temperature distribution, the value that depends on the geometric state of a fluid, and temperature difference between the top and bottom of the layer. Dynamical analysis of this system are determines the equilibritum point, the eigenvalues, and stability of each equilibrium point. This system have two equilibrium point. Based on the analysis, the first equilibrium point is unstable and the second equilibrium points is stable with certain conditions To find out the bifurcation of this system, 27 conditions were taken with different parameters. Taking these 27 conditions can be seen as a change in stability. Because of the stability changes, this system includes transcritical bifurcation. Formed of limit cycle is stable because the outside and inside the limit cycle approach the limit cycle.

Keywords: Bifurcation, Equilibrium Points, Lorenz System, Modified Lorenz System, Stability.

\section{Pendahuluan}

Berdasarkan Q.S. Al-Furqan ayat 48 , ayat tersebut menjelaskan bahwa angin adalah sebagai pertanda sebelum turunnya hujan. Kemudian pada tahun 1963, ada seorang pakar meteorologi yang membuktikannya, yaitu bernama Edward Lorenz dan penemuannya ini dikenal dengan sistem Lorenz. Sistem ini menggambarkan aliran angin di atmosfer untuk kebutuhan peramalan cuaca.

Sistem Lorenz merupakan sebuah model yang menggambarkan pergerakan angin di atmosfer yang mengalami turbulensi karena adanya perubahan temperatur [2]. Sistem Lorenz ini identik dengan kata chaos, yaitu perilaku dari suatu sistem yang memiliki kesensitifan terhadap kondisi awal [18]. Ini bermula ketika Edward Lorenz akan meramal cuaca, namun Edward menemukan sebuah perilaku yang 
tak biasa, yaitu lintasan yang tidak teratur. Jadi, apabila ada perubahan kecil pada kondisi awal akan merubah hasil akhir. Sehingga sistem ini sangat bergantung pada kondisi awal [2].

Secara matematis, sistem Lorenz merupakan persamaan diferensial biasa nonlinier [1]:

$$
\begin{gathered}
\dot{x}=a(y-x) \\
\dot{y}=c x-x z-y \\
\dot{z}=x y-b z
\end{gathered}
$$

Pergerakan angin ini dapat digambarkan dengan tiga variabel yang bergantung terhadap waktu, yaitu $x$ adalah intensitas gerak fluida, $y$ adalah temperatur horizontal, sedangkan $z$ adalah temperatur vertikal. Sistem Lorenz ini memiliki tiga parameter, yaitu $a, b$, dan $c$ yang merupakan parameter konstan bernilai positif, dimana $a=10, b=\frac{8}{3}$, dan $c=28$. Nilai $a$ adalah bilangan Prandtl yang merupakan nilai untuk menentukan ditribusi temperatur pada suatu aliran. $b$ merupakan nilai yang bergantung dengan keadaan geometri suatu fluida. Sedangkan $c$ adalah bilangan Rayleigh yang merupakan nilai perbedaan temperatur antara bagian atas dan bagian bawah lapisan [2].

\section{Metode}

Paper ini akan membahas sistem yang baru dari Sistem Lorenz sebelumnya, berikut ini adalah Sistem Lorenz yang telah dimodifikasi [1]:

$$
\begin{gathered}
\dot{x}=m(n y-x) \\
\dot{y}=o x-x z \\
\dot{z}=x y-n z
\end{gathered}
$$

\begin{tabular}{|c|c|c|c|c|}
\hline $\begin{array}{c}\text { Parameter/ } \\
\text { Variabel }\end{array}$ & Keterangan & Satuan & Dimensi & Interval \\
\hline$x$ & Intensitas gerak fluida & $\frac{1}{\text { waktu }}$ & {$[T]^{-1}$} & $x>0$ \\
\hline$y$ & Temperatur horizontal & ${ }^{0} \mathrm{C}$ & {$[M]^{0}[L]^{0}[T]^{0}$} & $-{ }^{0} C<y<{ }^{0} C$ \\
\hline$z$ & Temperatur vertikal | m & h'9at & {$[M]^{0}[E]^{0}[E]^{0}$} & $-{ }^{0} C<z<{ }^{0} C$ \\
\hline$m$ & $\begin{array}{c}\text { Nilai untuk menentukan } \\
\text { distribusi temperatur pada } \\
\text { suatu aliran. }\end{array}$ & ${ }^{0} C$ & {$[M]^{0}[L]^{0}[T]^{0}$} & $-{ }^{0} C<m<{ }^{0} C$ \\
\hline$n$ & $\begin{array}{l}\text { Nilai yang bergantung dengan } \\
\text { keadaan geometri suatu } \\
\text { fluida. }\end{array}$ & ${ }^{0} C$ & {$[M]^{0}[L]^{0}[T]^{0}$} & $-{ }^{0} C<n<{ }^{0} C$ \\
\hline$o$ & $\begin{array}{c}\text { Nilai perbedaan temperatur } \\
\text { antara bagian atas dan bagian } \\
\text { bawah lapisan. }\end{array}$ & ${ }^{0} C$ & {$[M]^{0}[L]^{0}[T]^{0}$} & $-{ }^{0} C<o<{ }^{0} C$ \\
\hline
\end{tabular}

dimana $x, y$, dan $z$ adalah variabel dan $m, n, o$ adalah parameter real.

Berikut ini keterangan dari masing-masing variabel dan parameter:

Tabel 2. Parameter dan Variabel

Untuk mendapatkan titik ekuilibrium pada sistem tersebut, misalkan $\dot{x}=\dot{y}=\dot{z}=0$. Sehingga diperoleh,

$$
\begin{aligned}
& P_{1}=(x, y, z)=(0,0,0) \\
& P_{2}=(x, y, z)=(n \sqrt{o}, \sqrt{o}, o)
\end{aligned}
$$

Selain itu, dari sistem pun didapat matriks Jacobi sebagai berikut: 


$$
J=\left[\begin{array}{ccc}
-m & m n & 0 \\
o-z & 0 & -x \\
y & x & -n
\end{array}\right]
$$

Setelah mendapatkan matriks Jacobi, substitusikan masing-masing titik ekuilibrium pada matriks Jacobi untuk mendapatkan nilai eigen. Ketika $\mathrm{P}_{1}=(x, y, z)=(0,0,0)$, maka diperoleh

$$
\begin{aligned}
& \lambda_{1}=-n \\
& \lambda_{2}=\frac{-m+\sqrt{m^{2}+4 m n o}}{2} \\
& \lambda_{3}=\frac{-m-\sqrt{m^{2}+4 m n o}}{2}
\end{aligned}
$$

Pada titik ini, kondisinya tidak stabil.

Ketika $\mathrm{P}_{2}=(x, y, z)=(n \sqrt{o}, \sqrt{o}, o)$, diperoleh persamaan karakteristik sebagai berikut:

$$
\lambda^{3}+(m+n) \lambda^{2}+\left(m n+n^{2} o\right) \lambda+2 m n^{2} o=0
$$

untuk menganalisis kestabilannya maka gunakan Routh-Hurwitz. Hasil analisisnya adalah titik ekuilibrium yang kedua ini stabil bersyarat apabila $(m+n)>\frac{2 m n^{2} o}{\left(m n+n^{2} o\right)}$.

Diberikan suatu fungsi sebagai berikut:

$$
\mathrm{L}(\mathrm{x}, \mathrm{y}, \mathrm{z})=\frac{\mathrm{x}^{2}}{2 m}+\frac{y^{2}}{2}+\frac{z^{2}}{2}
$$

Suatu fungsi dikatakan fungsi Lyapunov apabila memenuhi syarat sebagai berikut:

- $\mathrm{L}(x, y, z)>0$, karena fungsi mutlak bernilai positif.

- $\mathrm{L}(x, y, z)=0$ jika dan hanya jika $L(x, y, z)=(0,0,0)$

- $\mathrm{L}(x, y, z)$ bukan fungsi naik sehingga $\frac{d L}{d t}=\dot{L}<0$.

Fungsi di atas dikatakan fungsi Lyapunov dan stabil asimtotik bersyarat apabila memenuhi $x^{2}+n z^{2}>(n+$ o)xy.

Untuk mengetahui bifurkasi dari Sistem Lorenz Modifikasi ini, asumsikan kompartemen $z$ sebagai sebuah fungsi dari variabel $t$, sehingga untuk menganalisis bifurkasi ini menggunakan sistem

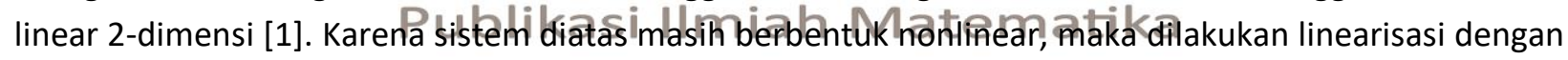
matriks Jacobian sebagai berikut:

$$
J=\left|\begin{array}{cc}
-m & m n \\
o-z & 0
\end{array}\right|
$$

Sehingga, diperoleh persamaan karakteristik beserta nilai eigennya sebagai berikut:

$$
\begin{gathered}
\lambda^{2}+m \lambda-m n(o-z)=0 \\
\lambda_{1}=\frac{-m+\sqrt{m^{2}+4 m n o-4 m n z}}{2} \\
\lambda_{2}=\frac{-m-\sqrt{m^{2}+4 m n o-4 m n z}}{2}
\end{gathered}
$$

\section{Hasil dan Diskusi}

Selanjutnya, dari persamaan (13) dapat diambil 27 kondisi dengan parameter yang berbeda-beda. Sedangkan untuk menganalisis kestabilannya, gunakan jumlah dan hasil kali akar-akar persamaan 
kuadrat. Apabila ingin mengetahui perubahan kestabilannya, substitusikan setiap parameter pada persamaan (14). Sehingga diperoleh sebagai berikut:

Tabel 3. Pengelompokkan Kestabilan

\begin{tabular}{|c|c|c|}
\hline Kestabilan Berubah & Tetap Stabil & Tetap Tidak Stabil \\
\hline$m>0, n=0, o=0$ & $m>0, n>0, o>0$ & $m<0, n>0, o>0$ \\
\hline$m>0, n=0, o<0$ & $m>0, n<0, o>0$ & $m<0, n<0, o<0$ \\
\hline$m>0, n=0, o>0$ & $m>0, n>0, o<0$ & $m<0, n>0, o<0$ \\
\hline & $m>0, n>0, o=0$ & $m<0, n=0, o<0$ \\
\hline & $m>0, n<0, o<0$ & $m<0, n<0, o>0$ \\
\hline & & $m<0, n<0, o=0$ \\
\hline & & $m<0, n=0, o=0$ \\
\hline & & $m>0, n<0, o=0$ \\
\hline & & $m<0, n>0, o=0$ \\
\hline & & $m<0, n=0, o>0$ \\
\hline
\end{tabular}

Dari pengambilan 27 kondisi, maka sistem Lorenz modifikasi ini termasuk dalam bifurkasi transcritical. Dapat dilihat pada tabel 3, ada 3 kondisi yang menyatakan bahwa adanya perubahan kestabilan yang awalnya tidak stabil menjadi stabil. Sistem ini termasuk ke dalam subcritical karena perubahan kestabilan yang dihasilkan adalah dari tidak stabil menjadi stabil.

Berikut ini merupakan phase portrait yang terbentuk dari pengambilan 27 kondisi dengan parameter yang berbeda-beda menggunakan software Maple:

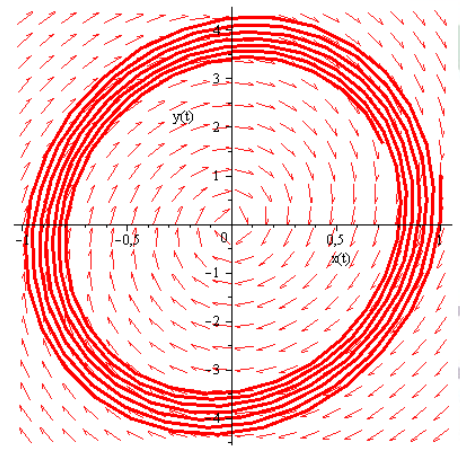

Gambar 1. $m>0, n>0, o>0$

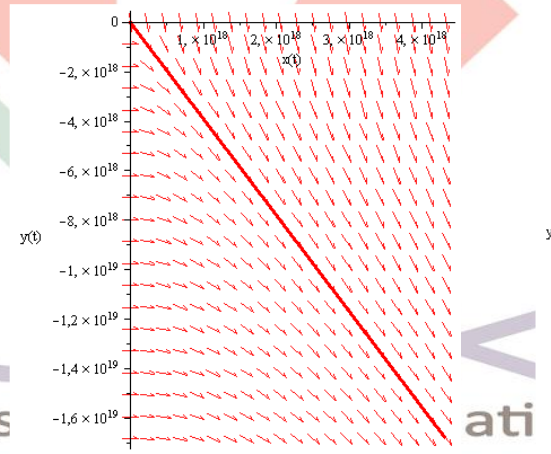

Gambar 2. $m<0, n>0, o>0$

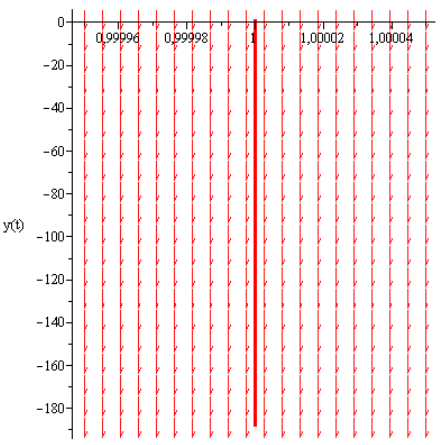

Gambar 3. $m=0, n>0, o>0$
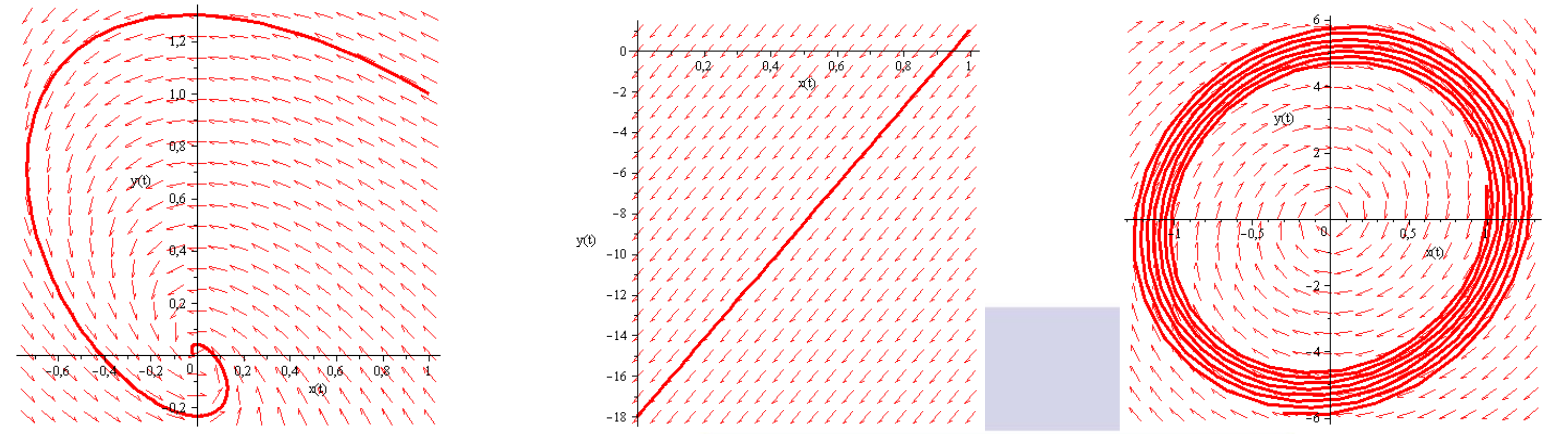
Gambar 4. $m>0, n<0,0>0$

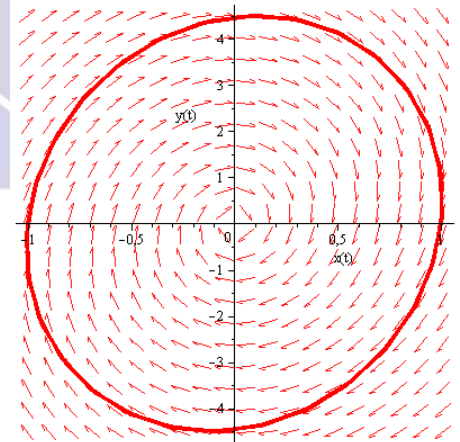

Gambar 7. $m>0, n>0, o=0$

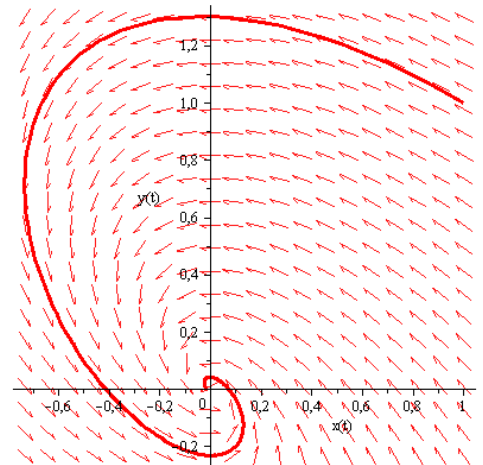

Gambar 10. $m>0, n<0,0<0$

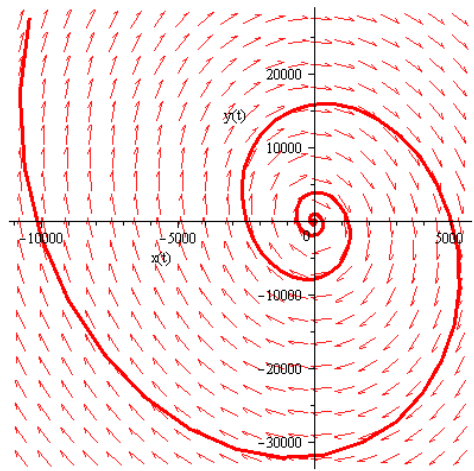

Gambar 13. $m<0, \mathrm{n}<0,0>0$

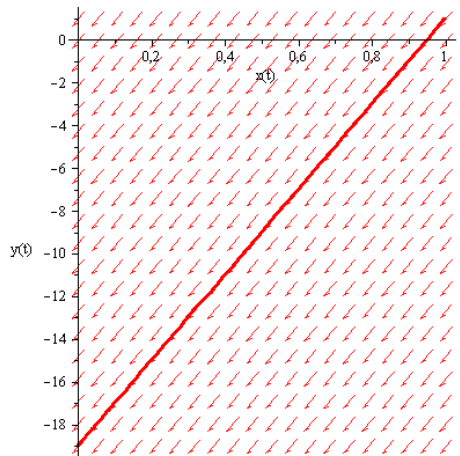

Gambar 16. $m>0, n=0, o=0$
Gambar 5. $m>0, n=0,0>0$

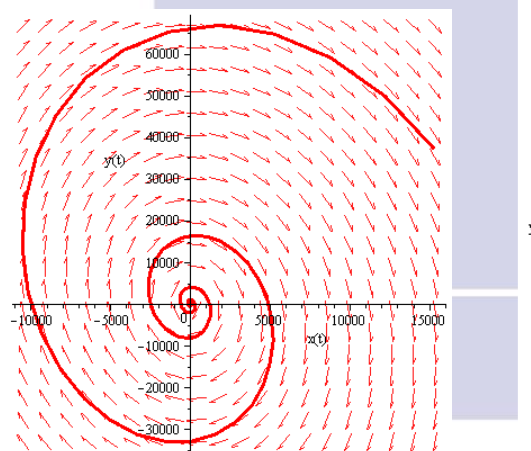

Gambar 8. $m<0, n<0,0<0$

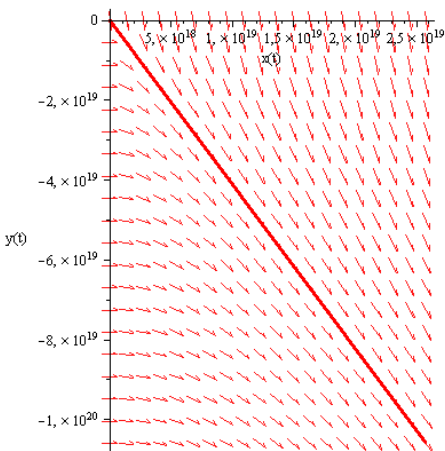

Gambar 11. $m<0, n>0, o<0$

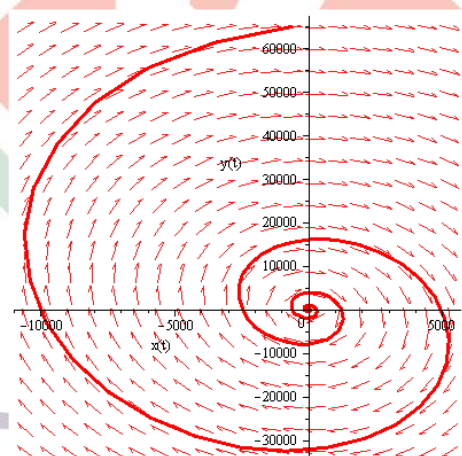

Gambar 14. $\mathrm{m}<0, \mathrm{n}<0, \mathrm{o}=0$

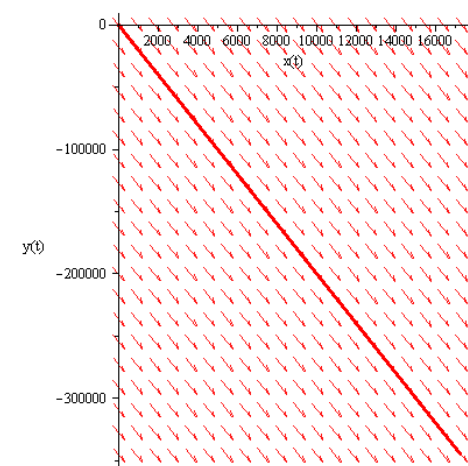

Gambar 17. $m<0, n=0, o=0$
Gambar 6. $m>0, n>0,0<0$

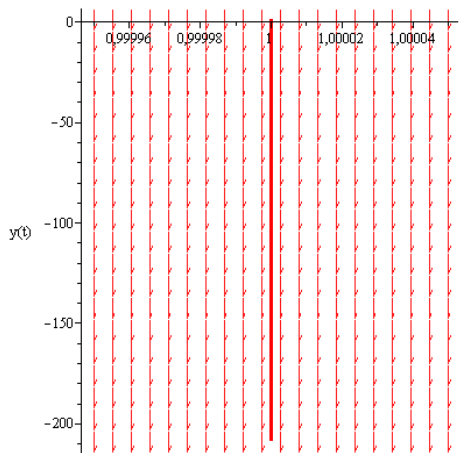

Gambar 9. $m=0, n<0,0<0$

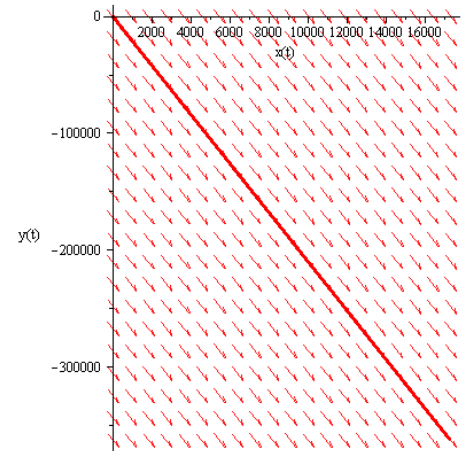

Gambar 12. $m<0, n=0,0<0$

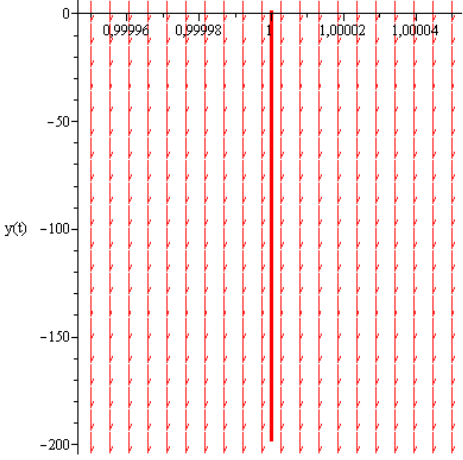

Gambar 15. $m=0, n=0, o=0$

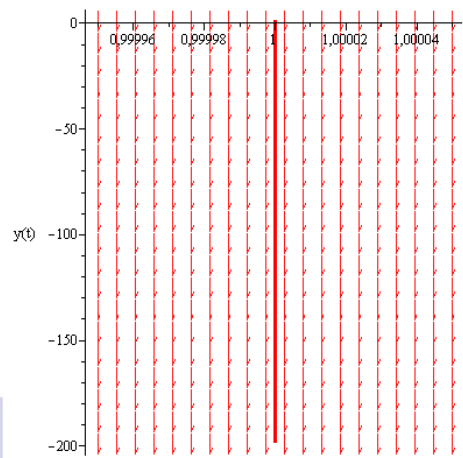

Gambar 18. $m=0, n>0, o=0$ 


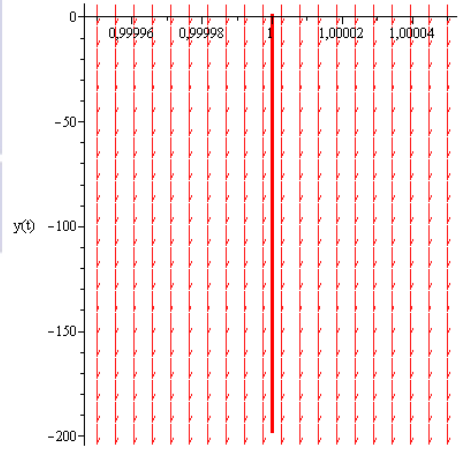

Gambar 19. $m=0, n<0,0=0$

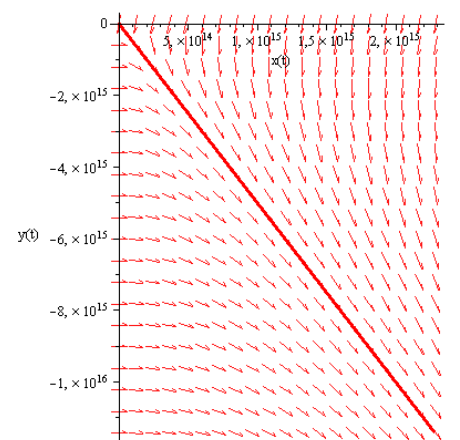

Gambar 22. $m>0, n<0, o=0$

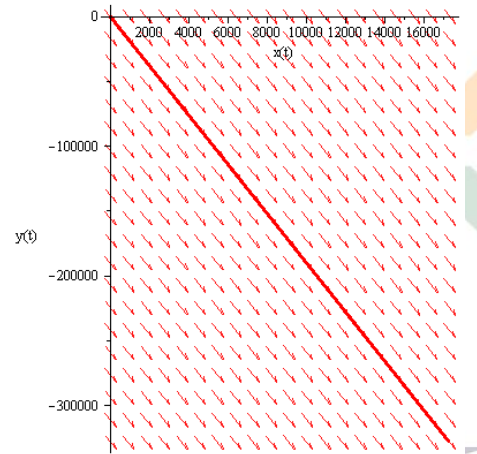

Gambar 25. $m<0, n=0,0>0$

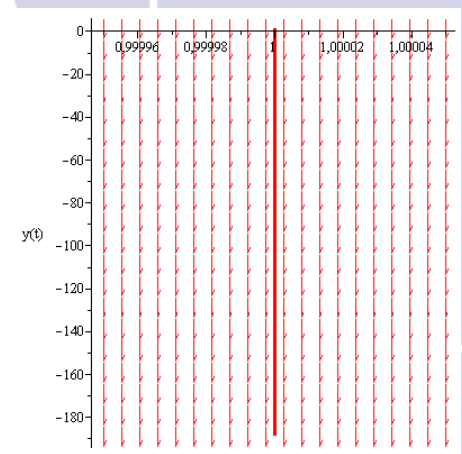

Gambar 20. $m=0, n=0,0>0$

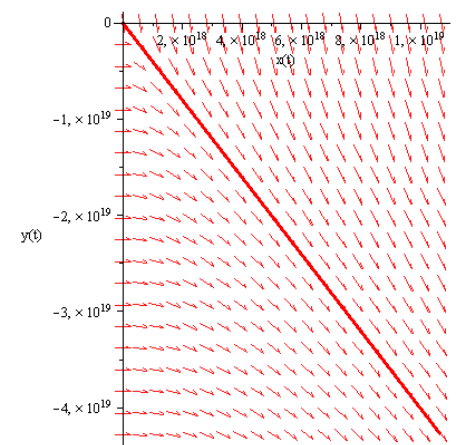

Gambar 23. $m<0, n>0, o=0$

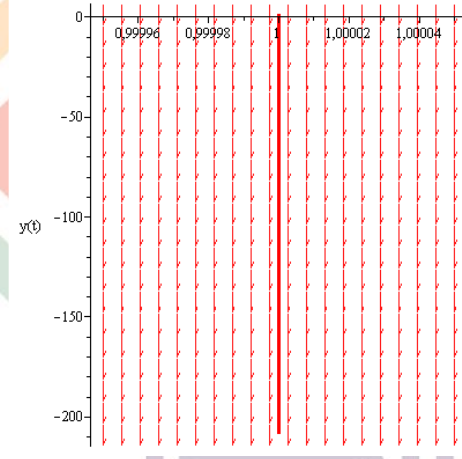

Gambar 26. $m=0, n>0,0<0$

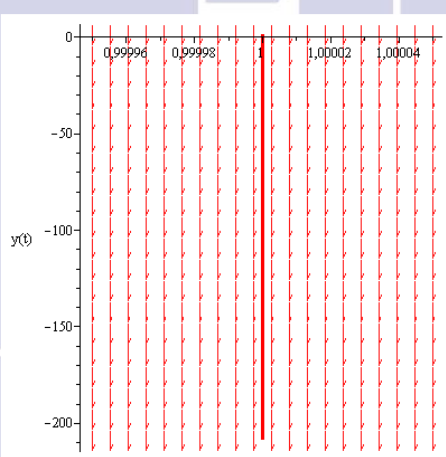

Gambar 21. $m=0, n=0,0<0$

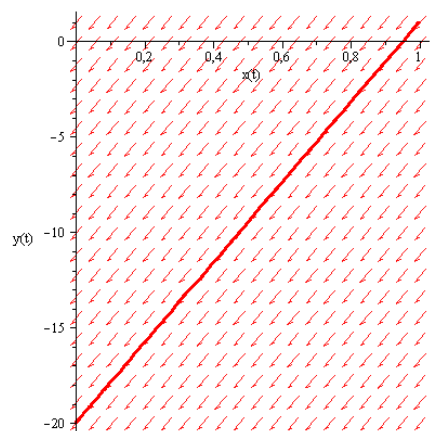

Gambar 24. $m>0, n=0, o<0$

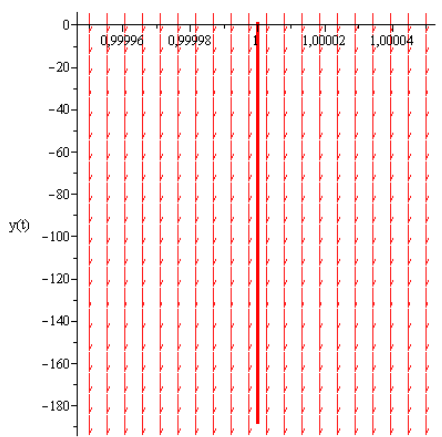

Gambar 27. $m=0, n<0,0>0$

Setelah mengetahui jenis bifurkasijyang terbentuk, selanjutnya akan dicari limit cycle dari sistem Lorenz modifikasi ini. Yang pertama dilakukan adalah lihat kembali kompartemen $x$ dan $y$ dengan mengubahnya ke koordinat polar dengan pendekatan titik ekuilibrium, sehingga diperoleh sebagai berikut:

$$
\begin{aligned}
& r^{\prime}=-m r \\
& \theta^{\prime}=o
\end{aligned}
$$

Dari konversi di atas, dapat dianalisis bahwa ketika $r=0$ maka $r^{\prime}=0$. Kemudian ketika $r<0$ maka $r^{\prime}>0$ sehingga orbit bergerak menuju tak hingga. Sedangkan ketika $r>0$ maka $r^{\prime}<0$ sehingga orbit bergerak menuju 0. Berikut ini gambaran limit cycle yang terbentuk dari persamaan (15) dengan mengambil sebarang jari-jari sebesar $r>0$.

\section{Kesimpulan}

1. Sistem Lorenz modifikasi ini memiliki 2 titik ekuilibrium. Untuk $P_{1}=(x, y, z)=(0,0,0)$, kestabilan dari titik ini tidak stabil. Pada $\mathrm{P}_{2}=(x, y, z)=(n \sqrt{o}, \sqrt{o}, o)$, analisis kestabilannya didapat dengan 
menggunakan metode Routh-Hurwitz, dimana titik ini stabil bersyarat apabaila memenuhi $(m+n)>\frac{2 m n^{2} o}{\left(m n+n^{2} o\right)}$.

2. Dengan menggunakan kestabilan Lyapunov, fungsi ini dikatakan fungsi Lyapunov dan stabil asimtotik bersyarat apabila memenuhi $x^{2}+n z^{2}>(n+o) x y$.

3. Bifurkasi pada sistem ini termasuk ke dalam bifurkasi transcritical karena ketika mengambil 27 kondisi dengan parameter yang berbeda-beda maka yang dihasilkan hanyalah perubahan kestabilan bukan penambahan atau pengurangan titik kritis. Untuk perubahan kestabilan yang terjadi adalah dari kondisi tidak stabil menjadi stabil, maka termasuk subcritical.

4. Mengenai limit cycle, ketika $r>0$ maka $r^{\prime}<0$ sehingga orbit bergerak menuju 0 . Kemudian ketika $\theta^{\prime}=c>0$ maka arah orbit berlawanan dengan arah jarum jam. Sehingga limit cycle yang terbentuk adalah limit cycle stabil karena lingkungan pada bagian luar maupun dalam limit cycle semuanya mendekati limit cycle.

\section{Ucapan Terima Kasih}

Penulis mengucapkan terima kasih kepada pihak-pihak yang telah membantu dalam penyusunan skripsi ini, diantaranya kepada kedua orangtua, keluarga, serta dosen pembimbing Matematika Fakultas Sains dan Teknologi, Universitas Islam Negeri Sunan Gunung Djati Bandung.

\section{Referensi}

[1] Loong Soon and Zabidin Salleh, "Dynamical Analysis of a Modified Lorenz System," Journal of Mathematics, 2012.

[2] Siti Nurlaela, "Sinkronisasi Chaos Sirkuit Lorenz Serta Aplikasinya dalam Sistem Kemanan Komunikasi," vol. V, Juni 2011.

[3] Morris W. Hirsch, Stephen Smale, and Robert L. Devaney, Differential Equation, Dynamical System, and an Introduction to Chaos. USA: Academic Press, 2004.

[4] Bayong Tjasyono HK., Karakteristik dan Sirkulasi Atmosfer. Jakarta: Badan Meteorologi Klimatologi dan Geofisika, 2012.

[5] I Wayan Sudiarta dan Tim Mahasiswa, Pengantar Meteorologi. Mataram: Universitas Mataram, 2013.

[6] A. D. Dalmedico, "History and Epistemology of Models: Meteorology (1946-1963) as a Case Study," , 2001, pp. 395-422.

[7] R. F. Gionardo, Weir. D. M., and Fox. P. W., A First Course in Mathematical Modeling (Third Edition). China: Machine Press, 2013.

[8] R. J. Iswanto, Pemodelan Matematika Aplikasi dan Terapannya edisi 1. Yogyakarta: Graha Ilmu, 2012.

[9] Dennis G. Zill, A First Course in Differential Equation with Modelling Applications.: Brooks/ Cole, 2009.

[10] Maulidiani, "Model Mangsa Pemangsa Parasit dengan Pemanenan Sebagai Kontrol Terhadap Penyakit," 2011.

[11] L. Perko, Differential Equation and Dynamical System. New York: Springer-Verlag Berlin Heidelberg, 1991.

[12] Howard Anton, Aljabar Linear Elementer Edisi ke-5. Jakarta: Erlangga, 1987.

[13] T. Sutojo, Teori dan Aplikasi Aljabar Linier dan Matriks. Yogyakarta: ANDI Yogyakarta dan UDINUS Semarang, 2010.

[14] Teknik Elektro ITB, Analisis Sistem Kendali. Bandung: ITB, 1998.

[15] Siti Shifatul Azizah, "Diskretisasi Model Lorenz dengan Analogi Persamaan Beda," Jurnal Cauchy, vol.

2, November 2012. 
[16] C. A. Danforth, Why the Weather is Unpredictable, an Experimental and Theoritical Study of Lorenz Equation. Lewiston: The Faculty of The Department of Mathematics ang The Department of Physics Bates College, 2001.

[17] F.R., Weir, M.D., Fox, W.P, Giordano, A First Course In Mathematical Modeling, Edisi ketiga. Republic China: China Mechine Press, 2003.

[18] C.E. Esterninho Meador, "Numerical Calculation of Lyapunov Exponents for Three-Dimensional Systems of Ordinary Differential Equations," Thesis, 2011.

[19] M. W. Hirsch, S. Smale, and R. L. Devaney, Differential Equations, Dynamical Systems, and an Introduction to Chaos. Elsevier, 2004.

[20] Guckenheimer John and Holmes, Nonlinear Oscillations, Dynamical Systems, and Bifurcations of Vector Fields. 1983.

[21] Mela Puspita, "Bentuk Normal Bifurkasi Hopf pada Sistem Umum Dua Dimensi," Jurnal Matematika UNAND, vol. 5

[22] Kuznetsov, Y.A., Elements of Applied Bifurcation Theory Second Edition. New York: Springer. 1998.

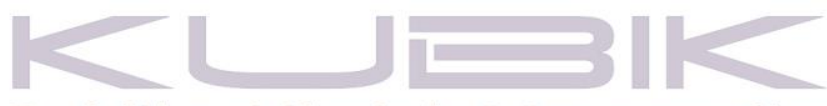

